\title{
The Effects of Lipid Nutrient Supplement (LNS) Feedings on the Improvement of Vitamin A and Zinc Levels on Children in Nusa Tenggara Timur Province
}

\author{
Andi Maryam \\ Universitas Indonesia Timur \\ Makassar, South Sulawesi, Indonesia
}

\begin{abstract}
The aim of this study is to assess the effects of Lipid Nutrient Supplement LNS feedings on the improvement of vitamin $A$ and zinc deficiency levels on children who aged between 6-23 months in South Middle Timor District of Nusa Tenggara Timur Province. The design of this research is Quasi experiment which is divided into 3 groups, which are; fed by LNS, fed by weaning/complementary food (MP ASI and control group which has not acquired the treatment but attained behavior communication change and vermicide.The population of the research is the family who has children between $6-23$ months of age and live in development areas of World Food Program in selected study locations. The subjects of the research are children between 6-23 months of age as many as 270 babies, by measuring the variable of vitamin A (RBP), zinc, protein, iron and vitamin $C$ levels. It was found that most of the nutritional intake before the intervention (zinc, vitamin A, protein, ion and vitamin C) was insufficient. The result of the study showed that the family's characteristic in term of parent's occupation was related to the children nutrition. It was found that there is a significant effect before and after the intervention on the LNS group and MP-ASI. The significant improvement is obtained by LNS group and MP-ASI for vit$\operatorname{amin} \mathrm{A}$ and zinc.
\end{abstract}

Keywords: Lipid Nutrient Supplement; Feedings; Zinc Levels

\section{INTRODUCTION}

Nationally, the result of Basic Health Survey Sandjaja et al. reported the decrease of malnutrition prevalence (the body weight by age) in children of 18.4 percent in 2007 become 17.9 percent in 2010 [1]. The undernutrition prevalence in 2007 decreased from $5.4 \%$ to $4.9 \%$ in 2010 but gained the improvement $5.7 \%$ in 2013.

The result of some studies showed that vitamin A is one of the essential nutritional substances for a human being. However, the consumption of food that contained the vitamin tends to be insufficient and is still low [2]-[4]. Based on this fact, the fulfillment of this substance from outside feeding becomes a critical issue.

Lipid Nutrient Supplement (LNS) is one of the Ready-touse Therapeutic Food, in the form of oil-based pasta and peanut butter like texture [5]. With those mentioned above, this research investigates the effect of LNS on the improvement of vitamin A and zinc levels before and after the interventions of LNS for three months compared to MP-ASI SUN and control groups. It is given to babies aged 6-23 months which is expected to produce a solution and evidencebased policy for the programs of the prevalence of vitamin A and zinc deficiencies, especially on children aged 6-23 months in the regency of South Middle Timor, NTT.

\section{RESEARCH METHOD}

This research used quasi experiment design which is divided into three groups. The subjects of the study are children aged between 6-23months. The size of the sample is just the same as the project research sample of World Food Program (WFP), for each group consists of 1200 children aged between $6-23$ months (the total for all groups are 3600 children) [6]. In the case of examining the biomarkers, it is only conducted on $20 \%$ of selected sample for each group. (240 of children for each group). It became 720 children in total who undergone the biomarkers examination.

The sample selection is determined by the inclusion criteria. The sample determination was held in local health center (Puskesmas) level by establishing the one which has the largest amount of children aged between 6-23months and is reachable as well as the founded regions of WFP.

The data were collected by several methods as follows: (1) The vitamin A data were taken by measuring RPB level in the blood plasma Enzyme Linked Immunosorbent ASSAY (ELISA) [7]; (2) The level of zinc serum in the blood is measured by Atomic Absorption Spectrophometry (AAS) [8]; (3) Sex, age group, education, occupation, health history, consumption obedience and the status while breastfeeding was attained by performing an interview with the mother of the child.

Data analysis is accomplished by using statistics test, either descriptive or analytic. They are Univariate analysis, ChiSquare, Paired T-Test and ANOVA. 


\section{RESULTS}

Based on the preliminary survey, it was found that the parents' occupation affects the income and the ability to supply food to their children. Most of the family income of the respondents is less than regional minimum wage (UMR) of South Middle Timor District that is Rp. 1.100.000.

After completing the screening of determinant variables, the related factors for the level of vitamin A are protein, paternal employed, paternal and maternal education. On the contrary, the factors for the Zinc are protein and the disease history.

TABLE I. THE FACTORS RELATED TO THE LEVEL OF VITAMIN A AND ZINC FOR CHILDREN AGED BETWEEN 6-23 MONTHS

\begin{tabular}{|l|c|c|c|}
\hline \multicolumn{1}{|c|}{ Variable } & B & SE & P \\
\hline Vitamin A (Mcg) & & & \\
\hline Protein & 0.416 & 0.127 & 0.001 \\
\hline Paternal Employed & 0.176 & 0.052 & 0.001 \\
\hline Paternal education & 0.113 & 0.058 & 0.053 \\
\hline Maternal employed & 0.077 & 0.063 & 0.220 \\
\hline Zink (mg) & & & \\
\hline Protein & 0.194 & 0.046 & 0.000 \\
\hline Morbidity in past & 0.076 & 0.021 & 0.000 \\
\hline
\end{tabular}

The data shows the increase of vitamin A and zinc level in the children aged 6-23 months after the intervention with the average values for vitamin A and zinc are 9.1 and 14.4, respectively. This figure can be seen in Table 3 as follows:

TABLE II. THE VALUES OF VITAMIN A AND ZINC LEVELS OF CHILDREN AGED 6-23 MONTHS AFTER THE INTERVENTION

\begin{tabular}{|l|c|c|c|c|}
\hline & $\begin{array}{c}\text { Vit.A be- } \\
\text { fore }\end{array}$ & $\begin{array}{c}\text { Vit.A af- } \\
\text { ter }\end{array}$ & $\begin{array}{c}\text { Zinc be- } \\
\text { fore }\end{array}$ & $\begin{array}{c}\text { Zinc af- } \\
\text { ter }\end{array}$ \\
\hline Mean & 240.7716 & 249.8491 & 42.7129 & 57.0852 \\
\hline $\mathrm{N}$ & 720 & 348 & 720 & 127 \\
\hline $\begin{array}{l}\text { Std. De- } \\
\text { viation }\end{array}$ & 147.68781 & $\begin{array}{c}220.6435 \\
8\end{array}$ & 48.93395 & 59.13182 \\
\hline Median & 209.2 & 232.468 & 30.98 & 45.73 \\
\hline
\end{tabular}

The analysis result shows that the children of age 6-23 months who are obedient in consuming LNS is $55.56 \%$ and MP-ASI is $51.14 \%$. It is illustrated in Table 4.3 . The result of the analysis shows that after the intervention, the level of RBP on LNS decreased with the value test of Paired T-test $\mathrm{p}=0.0001$. On the other hand, there is an improvement on MPASI after the intervention with the value of $p=0.009$ for zinc on LNS group and MP-ASI. The alteration of vitamin A status after the feeding of LNS is $83.8 \pm 21.7$ and MP-ASI is $210.5 \pm 184.6$. Meanwhile, the status of zinc after the feeding of LNS is $41.8 \pm 24.2$, and M-PASI is $10.6 \pm 4$.8. Furthermore, the change of vitamin A and zinc status is the lowest of the control group. It is illustrated in Table 4 as follows:
TABLE III. THE PICTURES OF THE CONSUMPTION OBEDIENCE OF LNS AND MP-ASI OF CHILDREN AGED 6-23 MONTHS

\begin{tabular}{|l|c|c|}
\hline \multirow{2}{*}{ Obedience } & LNS & MP-ASI \\
\cline { 2 - 3 } & $(\mathbf{n = 1 1 7})$ & $(\mathbf{n = 1 3 1})$ \\
\hline Not & $13(11.11 \%)$ & $19(14.5 \%)$ \\
\hline Yes, but not all & $39(33.33 \%)$ & $45(34.35 \%)$ \\
\hline Yes, all & $65(55.56 \%)$ & $67(51.14 \%)$ \\
\hline
\end{tabular}

TABLE IV. THE EFFECTS OF LNS AND MP-ASI FEEDINGS ON THE IMPROVEMENT OF VITAMIN A (RBP) AND ZINC LEVELS OF CHILDREN AGED 6-23

\begin{tabular}{|c|c|c|c|c|c|}
\hline \multirow[b]{2}{*}{ Variable } & \multirow{2}{*}{\begin{tabular}{|l} 
Before \\
(mean \\
\pm SD) \\
\end{tabular}} & \multirow{2}{*}{$\begin{array}{l}\text { After } \\
(\text { mean } \\
\pm S D) \\
\end{array}$} & \multirow{2}{*}{$\begin{array}{l}P(t- \\
\text { test })\end{array}$} & \multirow[b]{2}{*}{ Delta } & \multirow{2}{*}{$\begin{array}{c}\text { P } \\
\text { (ANO } \\
\text { VA) }\end{array}$} \\
\hline & & & & & \\
\hline \multicolumn{6}{|l|}{$\begin{array}{l}\text { Vitamin } \\
\mathrm{A}(\mathrm{RBP})\end{array}$} \\
\hline $\begin{array}{l}\text { LNS } \\
(\mathrm{n}=117)\end{array}$ & $\begin{array}{l}272.6 \\
\pm 152.8 \\
\end{array}$ & $\begin{array}{l}163.0 \\
\pm 185.9 \\
\end{array}$ & 0.0001 & $\begin{array}{l}-109.6 \\
\pm-36.8 \mathrm{a} \\
\end{array}$ & \multirow[t]{3}{*}{0.0001} \\
\hline $\begin{array}{l}\text { MP-ASI } \\
(n=131)\end{array}$ & $\begin{array}{l}276.8 \\
\pm 144.5 \\
\end{array}$ & $\begin{array}{l}348.6 \\
\pm 301.9\end{array}$ & 0.009 & $\begin{array}{l}71.8 \pm- \\
313.0 \mathrm{~b}\end{array}$ & \\
\hline $\begin{array}{l}\text { Control } \\
(\mathrm{n}=100)\end{array}$ & $\begin{array}{l}273.0 \\
\pm 190.8 \\
\end{array}$ & $\begin{array}{l}207.9 \\
\pm 130.5 \\
\end{array}$ & 0.008 & $\begin{array}{c}-65.2 \pm \\
242.1 \mathrm{a} \\
\end{array}$ & \\
\hline \multicolumn{6}{|l|}{ Zinc } \\
\hline $\begin{array}{l}\text { LNS } \\
(n=44)\end{array}$ & $\begin{array}{l}42.6 \\
\pm 34.5\end{array}$ & $\begin{array}{l}84.4 \\
\pm 58.7\end{array}$ & 0.000 & $\begin{array}{l}41.8 \\
\pm 24.2\end{array}$ & \multirow[t]{3}{*}{0.000} \\
\hline $\begin{array}{l}\text { MP-ASI } \\
(\mathrm{n}=34)\end{array}$ & $\begin{array}{l}53.2 \\
\pm 63.8 \\
\end{array}$ & $\begin{array}{l}63.8 \\
\pm 70.8 \\
\end{array}$ & 0.000 & $\begin{array}{l}10.6 \\
\pm 7.0 \\
\end{array}$ & \\
\hline $\begin{array}{l}\text { Control } \\
(n=49)\end{array}$ & $\begin{array}{l}32.9 \\
\pm 26.9\end{array}$ & $\begin{array}{l}41.3 \\
\pm 37.1 \\
\end{array}$ & 0.071 & $\begin{array}{l}8.4 \\
\pm 10.2 \\
\end{array}$ & \\
\hline
\end{tabular}

There is a significant difference which is found based on the result of the ANOVA test analysis for the level of vitamin A in each group, but the group of M-PASI and Control have a better chance for the improvement of vitamin A with the average value $=194.57328$ and $\mathrm{p}$-value $=0.000$. There is a significant difference of zinc level in LNS group vs. Control and there is no significant difference in a group of MP-ASI vs. Control and the $\mathrm{p}$-value $=0.219>\alpha=0.05$.

\section{DISCUSSION}

\section{A. The Effect of LNS and MP-ASI Feedings on the changes of Vitamin A Level}

Giving two sachets of LNS per day and complimentary food/MP-ASI of 3 sachets per day for children aged 6-23 months resulted in the insufficiency of vitamin $\mathrm{A}$ and zinc status before the intervention. The treatment was conducted in 90 days

The result of the study shows that the intervention can improve the level of vitamin A with the average of the improvement value is 83.8 with p-value $=0.000$, before the intervention is 171.4 to 255.2 . Moreover, the result showed that MP-ASI feedings can improve the level of vitamin A with 
the average improvement value is from 225.7 to 436.2 , the average improvement is 210,5 with $\mathrm{p}$-value $=0.000$, it can be assumed that there is a significant effect of the intervention. For the control group, the improvement gained 16.2 with pvalue $=0.000$ from 187.5 to 203.7 .

The difference analysis by performing ANOVA test showed that the average values of LNS vs. control groups were 171.06810 with the interval of $(95 \% \mathrm{CI}) 65,0947$ to 277.0415 , with the $\mathrm{p}$-value $=0.001<\alpha 0.05$. Thus, there is a significant difference in group LNS vs. Control.

The difference analysis of MP-ASI vs. control groups indicates that the difference of mean value is 194.57328 with interval $(95 \% \mathrm{CI}) 80.6844$ to 308.4622 , with $\mathrm{p}$-value $=0.000<\alpha$ 0.05 . Thus, there is a significant difference between MP-ASI group vs Control group.

By considering the analysis result of both groups, the group of MP-ASI is more dominant than Control group with the mean value is 194.57328 , compared to the group of LNS vs. Control which its mean value is 65,0947 only.

The result above confirmed that LNS could improve the level of vitamin A. It asserted the theory of LNS as the complementary food for breast milk which is rich in nutrients and categorized as a ready-to-use food for children aged $6-$ 24 months especially during the lean seasons (3 months). A sachet of LNS contains $800 \mathrm{mg}$ of vitamin A, while the requirement of vitamin $\mathrm{A}$ of each child is from $1200 \mathrm{IU}$ to 1500 IU. LNS contains energy, protein, fat and 23 vitamins and minerals such as vitamin $\mathrm{A}$, vitamin $\mathrm{B}$, vitamin $\mathrm{C}$, iron, protein, iodine, etc. which are required for the growth of children aged 6-24 months.

By the result of statistic test and t- test before and after the intervention on the group of LNS, it shows the significant effect on the level of vitamin A with the $p$ value=0,00. A significant effect is found in a group of MP-ASI with the improvement of vitamin A level, the value of $p=0.00$. There is no significant effect in control group for the second measurement with the value of $\mathrm{p}=0.580$.

The result of ANOVA shows that the feeding of MP-ASI is more dominant to the alteration of vitamin A level compared to LNS.

\section{B. The Effect of LNS and MP-ASI Feeding on the changes of Zinc Level}

The result of the research shows that the LNS feeding could increase the level of zinc with the average improvement is 41.8 value of $\mathrm{p}=0.000$ before the intervention is 42.6 to 84.4.

The result of the inquiry states that the feeding of MP-ASI could enhance the level of zinc with the mean from 53.2 to 63.8 and the mean 10.6 , the value of $p=0.000$. Thus, it is assumed that there is a significant effect of the intervention. The control group also attained the improvement of 8.4 with the value of $\mathrm{p}=0.071$.
Both of the groups, LNS or MP-ASI, each of them has a significant effect on the zinc level in children aged 6-23 months in South Middle Timor District of East Nusa Tenggara Province.

The ANOVA test is conducted to reveal the difference of the most dominant group to the change of zinc level. Analysis disclosed that the group of LNS vs. control have the different mean of 28.89622 with the interval $(95 \% \mathrm{CI}) \quad 9.1686$ up to 48.6238 , the value of $\mathrm{p}=0.002<\alpha 0.05$. Therefore, there is a significant difference between the group of LNS vs. control. Similar to this result, there is also no a significant difference between the group of MP-ASI vs. control.

By taking into account the result of both groups above, it shows that the group of LNS has a dominant difference of zinc level from the control group with mean value 28.89622, compared to MP-ASI group and control group which only has 14.97007 of the mean value.

From the result above, it can be asserted that LNS could increase the level of zinc. This fact is in the line of the theory of LNS as the complementary food of breast milk. A $16 \mathrm{mg}$ LNS per sachet contains zinc to fulfill the children requirements of zinc 3-7 mg per day. LNS is fortified with energy, protein, fat and 23 vitamins and minerals such as vitamin $\mathrm{A}$, vitamin $\mathrm{B}$, vitamin $\mathrm{C}$, protein, iron, iodine, and zinc which are required for the development and growth of children aged 6-24 months.

By the statistic test before and after the intervention of the groups, LNS generates a significant effect on the zinc level with the value of $p=0,00$. Furthermore, the group of MP-ASI obtained the significant effect in increasing the level of zinc, with the value of $p=0.00$. Meanwhile, there is no significant influence on the second measurement with the value of $\mathrm{p}=0.071$

The result of the ANOVA test indicates that the feeding of LNS is more dominant on the change of zinc level compared to MP-ASI on children aged 6-23 months in South Middle Timor District of Nusa Tenggara Timur Province.

\section{CONCLUSION}

It can be concluded statistically that the result of this research asserts 95\% the feeding of Lipid-based nutrient supplement (LNS) could escalate the level of zinc in children aged 6-23 months in South Middle Timor District of Nusa Tenggara Timur (NTT) province. Moreover, it also assured the feedings of Lipid-based nutrient supplement (LNS) has a significant effect on the improvement of vitamin A level in the children. For the feedings of MP-ASI, it could increase the level of Vitamin A and accelerate the level of zinc of the children aged 6-23 months in South Middle Timor District of Nusa Tenggara Timur (NTT) province. The result of this study confirmed that in the case of improving the balanced level of vitamin A and zinc, then LNS and MP-ASI must be fed st the same time to the children aged 6-23 months in South Middle Timor District of Nusa Tenggara Timur Province. 


\section{REFERENCES}

[1] S. Sandjaja et al., 'Food consumption and nutritional and biochemical status of 0. 5-12-year-old Indonesian children: the SEANUTS study', Br. J. Nutr., vol. 110, no. S3, pp. S11-S20, 2013.

[2] S. S. Gropper and J. L. Smith, Advanced nutrition and human metabolism. Cengage Learning, 2012.

[3] J. Mann and S. Truswell, Essentials of human nutrition. Oxford University Press, 2012.

[4] F. Burchi, J. Fanzo, and E. Frison, 'The role of food and nutrition system approaches in tackling hidden hunger', Int. J. Environ. Res. Public Health, vol. 8, no. 2, pp. 358-373, 2011.

[5] M. Arimond et al., 'Considerations in developing lipid- based nutrient supplements for prevention of undernutrition: experience from the International Lipid- Based Nutrient Supplements (iLiNS) Project', Matern. Child Nutr., vol. 11, no. S4, pp. 31-61, 2015.

[6] D. Wiesmann, L. Bassett, T. Benson, and J. Hoddinott, Validation of the World Food Programme s Food Consumption Score and Alternative Indicators of Household Food Security. Intl Food Policy Res Inst, 2009.

[7] M. Al-Tamimi, F.-T. Mu, M. Moroi, E. E. Gardiner, M. C. Berndt, and R. K. Andrews, 'Measuring soluble platelet glycoprotein VI in human plasma by ELISA', Platelets, vol. 20, no. 3, pp. 143-149, 2009.

[8] M. N. Rashed, M. M. Ahmed, A. F. Al-Hossainy, and S. M. Abd, 'Trends in speciation analysis of some heavy metals in serum of patients with chronic hepatitis $\mathrm{C}$ and chronic hepatitis $\mathrm{B}$ using differential pulse adsorptive stripping voltammetric measurement and atomic absorption spectrophotometry', J. Trace Elem. Med. Biol., vol. 24, no. 2, pp. 138$145,2010$. 